Bangladesh J. Plant Taxon. 28(2): 441-449, 2021 (December)

(C) 2021 Bangladesh Association of Plant Taxonomists

DOI: https://doi.org/10.3329/bjpt.v28i2.57139

\title{
STEM ANATOMICAL DESCRIPTORS OF FOUR SESBANIA SCOP. SPECIES AND THEIR SYSTEMATIC IMPLICATION
}

\author{
Sontosh C. Chanda ${ }^{1}$, Md. Ashik Mia, Ashaduzzaman Sagar \\ AND A.K.M. Golam SARWAR* \\ Laboratory of Plant Systematics, Department of Crop Botany, \\ Bangladesh Agricultural University, Mymensingh 2202, Bangladesh
}

Keywords: Sesbania bispinosa; S. cannabina; S. rostrata; S. sesban; Vascular bundle; AHC.

\begin{abstract}
Stem anatomical features of four Sesbania Scop. species viz. S. bispinosa (Jacq.) W. Wight, S. cannabina (Retz.) Poir., S. sesban (L.) Merr., and S. rostrata Bremek. \& Oberm., were examined to add some insights for identification of these species using quantitative anatomical descriptors. Sesbania stem is composed of epidermis, cortex, vascular tissues - phloem, cambium zone and xylem, and pith, which exhibit significant variations among the species in terms of their area and thickness. Sesbania sesban showed the largest area and widest epidermal cells. The close relationship between S. bispinosa and S. rostrata was found in the stem anatomical descriptors. Moreover, S. rostrata and S. cannabina were closer to some extent according to some anatomical descriptors; also rationalizing the external morphological similarities of these species. A dichotomous key of the studied Sesbania species was made. Dendrograms based on Agglomerative Hierarchical Cluster analysis of stem anatomical descriptors also confirmed close relationships identified in previous phylogenetic analyses.
\end{abstract}

\section{Introduction}

The genus Sesbania Scop. includes about 70 species of which 27 species produce nodules (De Faria et al., 1989; Farruggia et al., 2018). Sesbania can fix atmospheric nitrogen through LegumeRhizobium symbiosis and form nitrogen-fixing nodules on its roots, surprisingly $S$. rostrata forms nodules both on root and stem (Allen and Allen, 1981). The Sesbania species are broadly used and cultivated in agroforestry for soil improvement, as green manures and other products (Evans, 1990). The economic importance of Sesbania, especially in Africa and Asia, comprises shade plants, windbreaks, cover crops, ornamentals, fish poisons (source of isoflavones), fibre sources, construction materials, food and medicinal uses for both humans and livestock (Gillett, 1963; Powell et al., 1976; Laladhas et al., 2010; Mythilli and Ravindhran, 2012), and bioremediation of lead, zinc and copper from industrial discharged sites and contaminated soils as well (Qadir et al., 2002; Sahi et al., 2002; Yang et al., 2003; Branzini et al., 2012). In Bangladesh, Sesbania is represented by 5 species viz. S. bispinosa (Jacq.) W. Wight, S. cannabina (Retz.) Pers., S. grandiflora (L.) Pers., S. javanica Miq. and S. sesban (L.) Merr. (Ahmed et al., 2009); among these, three species viz. S. sesban, S. bispinosa and S. cannabina, and an exotic species, S. rostrata Bremek. \& Oberm., are widely cultivated as green manure crops. The first three species are commonly known as dhaincha and the last one is African dhaincha (Sarwar et al., 2015). However, the identification of three native dhaincha species, especially $S$. bispinosa and $S$. cannabina is very difficult and confusing to separate in the field based on morphological features.

*Corresponding author, Email: drsarwar@bau.edu.bd

${ }^{1}$ Agricultural Training Institute, Ishwardi, Pabna, Bangladesh 
Several plant micro-morphological features including stem anatomical structure provide evidence connecting to the interrelationships of higher taxonomic groups, such as families, sections and tribes and serve to generate true resemblances of genera having indecisive taxonomic status (Metcalfe and Chalk, 1950; Aziagba and Okeke, 2017); although many anatomical characters are influenced by environmental factors (Metcalfe and Chalk, 1950). Anatomical features of the stem, leaf and other plant parts are used for identification and inferring taxonomic relationships among the taxa in many plant families including Leguminosae (Barykina and Kramina, 2006; Aziagba and Okeke, 2017; Nwachukwu et al., 2017). Several studies have been made on the utility of different morphological descriptors for the better identification of Sesbania species (Prodhan et al., 1998; Prodhan and Sarkar, 2002; Sarkar and Prodhan, 2001; Sarwar et al., 2015; Chanda et al., 2018, 2019a,b, 2020a,b, 2021). The present study was undertaken to investigate quantitative stem anatomical descriptors to add new insight for the identification of closely related Sesbania species.

\section{Materials and Methods}

Healthy mature seeds of four Sesbania species were collected from the Laboratory of Plant Systematics, Department of Crop Botany, Bangladesh Agricultural University. Seeds were previously collected from the field during field surveys, multiplied, identified and maintained/stored in the Laboratory. The plants were raised in the Field Laboratory of the Department of Crop Botany in 2017 following Chanda et al. (2020a). Stem samples, of 60 days old, of four Sesbania species were collected from the experimental field and preserved in vials containing FAA solution for further anatomical studies (Ruzin, 1999).

For anatomical exploration, both freehand sectioning and paraffin methods of microtechniques were followed (Prodhan and Sarkar, 2002). The paraffin sections were made habitually on the outcome of hand sections. After proper dehydration with ethyl alcohol and clearance with xylene, the sections were stained with safranin and fast green and mounted in Canada balsam (Ruzin, 1999; Sarkar and Prodhan, 2001; Prodhan and Sarkar, 2002). Three cross-sections from at least three different individual plants of each species were measured for each sample to assess the constancy of anatomical features. The length/width and size were measured under $\times 4,10$ and 40 magnifications using an optical microscope with Carl Zeiss Primo Star camera Model Axiocam ERc5s. Ten replicated measurements focusing lengths/width and size (area) were done on each slide and thirty (3x10) measurements for individual descriptors (Fig. 1). For individual cell lengths/width, measurements were done at three positions (central and two sides from the centre) and the average value was used as a single replicate. The diameter was measured through the longest axis of the xylem vessel.

The collected data were analyzed following the ANOVA using the statistical computer package program MSTAT-C. The mean differences of different parameters among the species were adjudged with Duncan's New Multiple Range Test (DMRT) (Gomez and Gomez, 1984). The agglomerative hierarchical cluster (AHC) analysis was performed on the dissimilarity of accession characteristics and the dendrogram was generated using the XLStat software program (https://www.xlstat.com/en/).

\section{Results and Discussion}

Sesbania species stem comprises four distinct layer/region(s) - epidermis, cortex, vascular zone, and pith, which are common phenomena of dicot stem ultrastructure (Fig. 2a-d). However, significant variations were observed in different stem anatomical components (Table 1). 
Table 1. Dimensions of anatomical descriptors in stem of four Sesbania species.

\begin{tabular}{|c|c|c|c|c|c|c|c|c|c|c|}
\hline \multirow[t]{2}{*}{ Species } & \multirow{2}{*}{$\begin{array}{c}\text { Thick- } \\
\text { ness of } \\
\text { cuticle } \\
(\mu \mathrm{m})\end{array}$} & \multicolumn{3}{|c|}{ Epidermal cell } & \multicolumn{2}{|c|}{ Hypodermal cell } & \multicolumn{2}{|c|}{ General cortex cell } & \multicolumn{2}{|c|}{ Endodermal cell } \\
\hline & & $\begin{array}{l}\text { Size } \\
\left(\mu \mathrm{m}^{2}\right)\end{array}$ & $\begin{array}{l}\text { Width } \\
(\mu \mathrm{m})\end{array}$ & $\begin{array}{l}\text { Wall thick- } \\
\text { ness }(\mu \mathrm{m})\end{array}$ & $\begin{array}{l}\text { Width } \\
(\mu \mathrm{m})\end{array}$ & $\begin{array}{c}\text { Size } \\
\left(\mu \mathrm{m}^{2}\right)\end{array}$ & $\begin{array}{l}\text { Width } \\
(\mu \mathrm{m})\end{array}$ & $\begin{array}{c}\text { Wall } \\
\text { thickness } \\
(\mu \mathrm{m})\end{array}$ & $\begin{array}{c}\text { Size } \\
\left(\mu \mathrm{m}^{2}\right)\end{array}$ & $\begin{array}{l}\text { Width } \\
(\mu \mathrm{m})\end{array}$ \\
\hline S. bispinosa & $6.02 \mathrm{c}$ & $857.9 \mathrm{ab}$ & $23.6 \mathrm{~b}$ & $3.50 \mathrm{~b}$ & $113.6 \mathrm{c}$ & $740.2 \mathrm{bc}$ & $32.3 \mathrm{~b}$ & $2.05 \mathrm{c}$ & $1060.2 \mathrm{~b}$ & $24.3 \mathrm{bc}$ \\
\hline S. cannabina & $7.56 \mathrm{a}$ & $667.8 \mathrm{~b}$ & $22.3 \mathrm{~b}$ & $1.52 \mathrm{c}$ & $163.5 \mathrm{ab}$ & $814.1 \mathrm{~b}$ & $62.2 \mathrm{a}$ & $2.94 \mathrm{a}$ & $1220.8 \mathrm{a}$ & $32.7 \mathrm{a}$ \\
\hline S. rostrata & $7.19 \mathrm{ab}$ & $693.2 \mathrm{~b}$ & $23.4 \mathrm{~b}$ & $4.27 \mathrm{ab}$ & $177.4 \mathrm{a}$ & $627.1 \mathrm{c}$ & $31.03 \mathrm{~b}$ & $2.25 \mathrm{bc}$ & $1029.4 \mathrm{~b}$ & $29.2 \mathrm{ab}$ \\
\hline S. sesban & $6.44 \mathrm{bc}$ & $999.8 \mathrm{a}$ & $28.3 \mathrm{a}$ & $4.82 \mathrm{a}$ & $144.2 \mathrm{~b}$ & 968.7 a & $33.08 \mathrm{~b}$ & $2.64 \mathrm{ab}$ & $1061.1 \mathrm{~b}$ & $21.7 \mathrm{c}$ \\
\hline $\begin{array}{l}\text { Level of } \\
\text { Significance }\end{array}$ & $*$ & $*$ & $*$ & $* *$ & $* *$ & $* *$ & $* * *$ & $*$ & $*$ & $* *$ \\
\hline $\mathrm{LSD}_{0.05}$ & 1.04 & 223.0 & 3.09 & 1.24 & 23.6 & 146.9 & 3.94 & 0.53 & 132.5 & 5.36 \\
\hline \multicolumn{11}{|c|}{ Right side of the table. } \\
\hline \multirow{2}{*}{$\begin{array}{l}\text { Vascular } \\
\text { cylinder } \\
\text { width } \\
(\mu \mathrm{m})\end{array}$} & \multirow{2}{*}{$\begin{array}{l}\text { Bundle } \\
\text { cap } \\
\text { width } \\
(\mu \mathrm{m})\end{array}$} & \multirow{2}{*}{$\begin{array}{l}\text { Phloem } \\
\text { width } \\
(\mu \mathrm{m})\end{array}$} & \multicolumn{2}{|c|}{ Sieve tube } & \multirow{2}{*}{$\begin{array}{c}\text { Cambial } \\
\text { layer } \\
\text { thickness } \\
(\mu \mathrm{m})\end{array}$} & \multirow[t]{2}{*}{$\begin{array}{c}\text { Xylem } \\
\text { thickness } \\
(\mu \mathrm{m})\end{array}$} & \multicolumn{2}{|c|}{$\begin{array}{r}\text { Xylem Vessel } \\
\text { diameter }(\mu \mathrm{m})\end{array}$} & \multicolumn{2}{|c|}{$\begin{array}{c}\text { Size of pith cell } \\
\left(\mu \mathrm{m}^{2}\right)\end{array}$} \\
\hline & & & $\begin{array}{l}\text { Size } \\
\left(\mu \mathrm{m}^{2}\right)\end{array}$ & $\begin{array}{l}\text { Wall thickness } \\
\qquad(\mu \mathrm{m})\end{array}$ & & & Meta- & Proto- & Peripheral & Central \\
\hline 187.48 a & 30.18 & $32.41 \mathrm{a}$ & $872.3 \mathrm{a}$ & $3.20 \mathrm{ab}$ & $27.8 \mathrm{bc}$ & $118.28 \mathrm{a}$ & $93.0 \mathrm{a}$ & $43.3 \mathrm{a}$ & $158.7 \mathrm{a}$ & $387.6 \mathrm{a}$ \\
\hline $173.99 \mathrm{~b}$ & 30.78 & $28.17 \mathrm{~b}$ & $640.9 \mathrm{c}$ & $4.16 \mathrm{a}$ & $22.4 \mathrm{c}$ & $92.98 \mathrm{~b}$ & $39.7 \mathrm{~d}$ & $26.6 \mathrm{~b}$ & $181.4 \mathrm{a}$ & $312.0 \mathrm{~b}$ \\
\hline 190.99 a & 30.23 & $26.40 \mathrm{~b}$ & $720.7 \mathrm{~b}$ & $4.15 \mathrm{a}$ & $32.2 \mathrm{ab}$ & $121.65 \mathrm{a}$ & $74.4 \mathrm{~b}$ & $27.5 \mathrm{~b}$ & $164.5 \mathrm{a}$ & $295.1 \mathrm{~b}$ \\
\hline $154.19 \mathrm{c}$ & 28.44 & $28.13 \mathrm{~b}$ & $414.6 \mathrm{~d}$ & $2.98 \mathrm{~b}$ & $35.9 \mathrm{a}$ & $85.17 \mathrm{c}$ & $62.2 \mathrm{c}$ & $40.1 \mathrm{a}$ & $115.9 \mathrm{~b}$ & $295.8 \mathrm{~b}$ \\
\hline$* * *$ & NS & $* * *$ & $* * *$ & $*$ & $* *$ & $* * *$ & $* * *$ & $*$ & $*$ & $* * *$ \\
\hline 5.23 & 2.32 & 2.06 & 39.5 & 0.97 & 5.90 & 3.9 & 7.17 & 12.2 & 36.9 & 30.8 \\
\hline
\end{tabular}

In a column figure (s) with the same letter do not differ significantly at $5 \%$ level by LSD Test; $*=$ Significant at $5 \%$ level, $* *=$ Significant at $1 \%$ level,

$* * *=$ Significant at $0.1 \%$ level $;$ LSD $=$ Least Significant Difference.

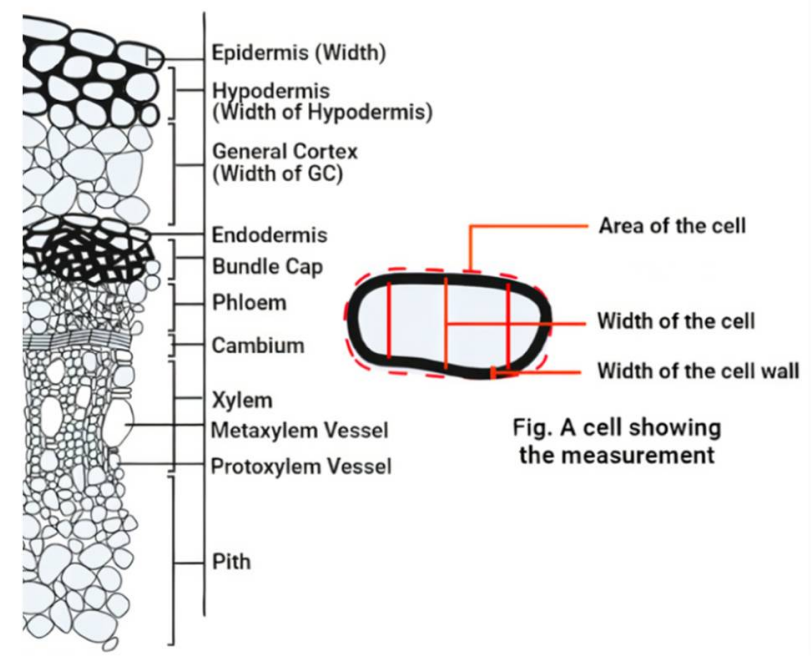

T.S. of Sesbania spp.

Fig.1. Schematic diagram of transverse section of a Sesbania sp. 


\section{Epidermis}

The transverse section of the stem of all Sesbania species showed a single-layered epidermis covered with a thick cuticle. The epidermal cells are more or less square or slightly rectangular in shape (Fig. 2c). The result of previous studies, the single layer of epidermis with slightly rectangular cells, of Sesbania spp. were in an agreement with the present study (Prodhan and Sarkar, 2002; Sarkar and Prodhan, 2002). Statistically, the largest epidermal cell area was observed in $S$. sesban $\left(999.8 \mu \mathrm{m}^{2}\right)$ followed by $S$. bispinosa $\left(857.9 \mu \mathrm{m}^{2}\right)$ and the lowest in $S$. cannabina $\left(667.8 \mu \mathrm{m}^{2}\right)$ followed by S. rostrata $\left(693.2 \mu \mathrm{m}^{2}\right.$ ) (Table 1). Furthermore, the width of epidermal parenchyma cells was preeminent in $S$. sesban $(28.3 \mu \mathrm{m})$ whereas lowest in $S$. cannabina $(22.3 \mu \mathrm{m})$. In the case of an epidermal cell wall, the maximum value was recorded in $S$. sesban and it was statistically similar to $S$. rostrata. However, statistically significant results were found in S. rostrata, S. bispinosa and S. cannabina in thickness of epidermal cell wall. The thinnest epidermal cell wall was observed in S. cannabina $(1.53 \mu \mathrm{m})$. On the contrary, the thickest cuticle was observed in $S$. cannabina and it was statistically insignificant to $S$. rostrata and significant to $S$. bispinosa (Table 1). From Table 1, it is evident that $S$. bispinosa and S. rostrata exhibited similar results followed by $S$. cannabina and S. sesban in terms of their epidermal characteristics which supported the taxonomic evidence and cladistics relationship of different Sesbania species (Farruggia et al., 2018). In addition, S. rostrata and S. cannabina were also closer according to their epidermal attributes that also justifies the observations reported by Chanda et al. (2020b) for the identification of Sesbania species based on external morphological descriptors.
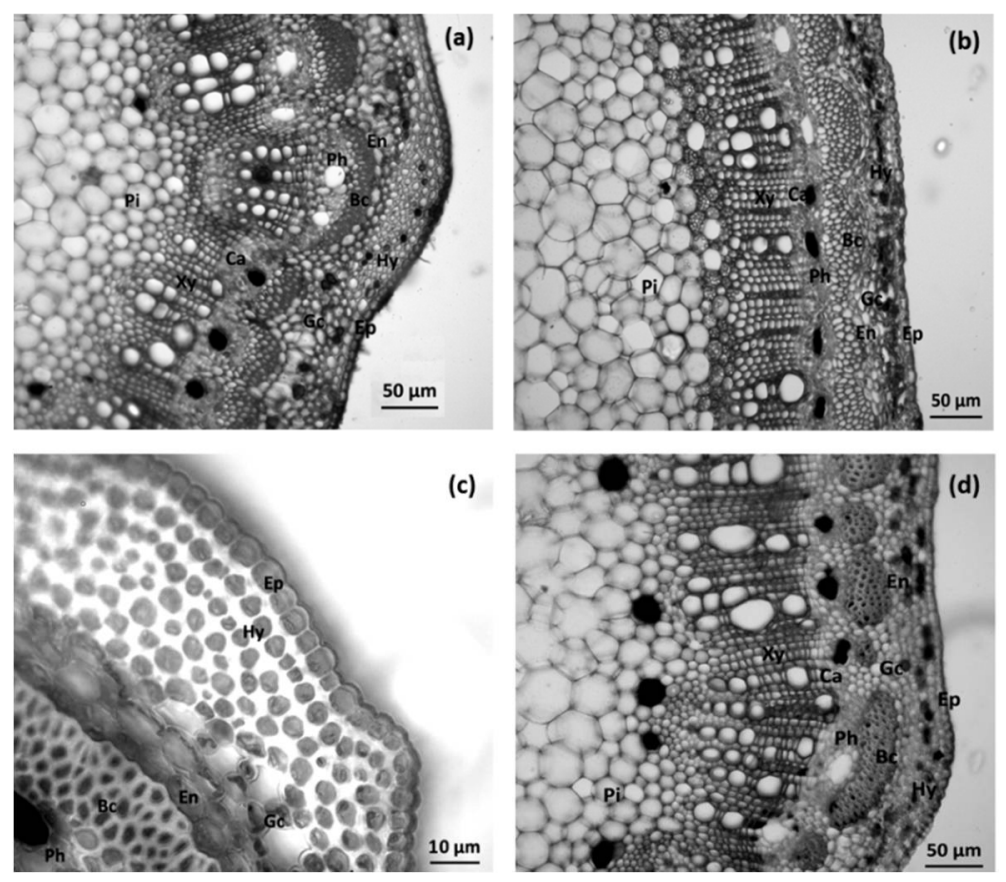

Fig. 2. Transverse section (TS) of Sesbania stem. a. S. cannabina, b. S. sesban, c. S. rostrata, d. S. bispinosa. Ep: Epidermis; Hy: Hypodermis; Gc: General cortex; En: Endodermis; Bc: Bundle cap; Ph: Phloem; Ca: Cambium; Xy: Xylem and Pi: Pith. 


\section{Cortex}

Just beneath the epidermis, the position belongs to the cortex. It is a few to several cells in thickness. The cortex comprises (i) the hypodermis, (ii) the general cortex and (iii) the endodermis, which is located next to the vascular bundle cap (Fig. 2c). The number of cortical layers varies according to the age, size and level of secondary growth of the organ concerned (Prodhan and Sarkar, 2002). The collenchymatous hypodermal layers varied from two to six among the species. The cortex, especially the endodermis, is disorganized and disintegrated due to the stress of secondary growth (Fig. 2). Results revealed that the thickest hypodermal layer was found in $S$. rostrata $(177.4 \mu \mathrm{m})$ followed by $S$. cannabina $(163.5 \mu \mathrm{m}), S$. sesban $(144.2 \mu \mathrm{m})$ and $S$. bispinosa $(113.6 \mu \mathrm{m})($ Table 1). There were significant variations of individual hypodermal cell areas among the Sesbania species. The largest hypodermal cell was observed in $S$. sesban and the smallest in S. rostrata (Table 1). The thickness of the general cortex was highest in S. cannabina whereas the other three species exhibited statistically similar and lowest thickness. In addition, the thickness of the cell wall of ground tissue exhibited highest in S. cannabina and lowest in $S$. bispinosa. Lots of tanniniferous cells are found in the middle zoned cortex (Fig. 2, Sarkar and Prodhan, 2001). Secretory cells are common in the cortex of many plants. The endodermis is a wavy layer of one cell in thickness. It lies at the innermost boundary of the cortex (Fig. 2). From Table 1, S. cannabina exhibited the largest endodermal cell $\left(1220.8 \mu \mathrm{m}^{2}\right)$ which was statistically different from other species. The width of the endodermal parenchyma cells was also statistically significant and the highest width was found in S. cannabina $(32.7 \mu \mathrm{m})$ whereas the lowest was in S. sesban $(21.7 \mu \mathrm{m})$. Results from the cortical area brought to light that statistical similarities were found among S. bispinosa and S. rostrata in most of the cases. With some exceptions, S. rostrata and $S$. cannabina were statically identical according to their hypodermal thickness and width of the endodermis. These anatomical findings justified the phylogenetic relationships among the Sesbania species and the external morphological similarities among the species (Farruggia et al., 2018; Chanda et al., 2020b). Chanda et al. (2020b) reported close similarities in stem base diameter of $S$. rostrata and $S$. bispinosa which confirmed the present results of the anatomical measurements.

\section{Vascular bundle}

The vascular bundles, consisting of bundle cap, phloem, cambium and xylem, are arranged in a ring as seen in the transverse section of Sesbania species (Fig. 2). The vascular bundles are of two types - large and small, and they were positioned alternately. However, one or two small vascular bundles in between two large bundles were also observed in Sesbania (Sarkar and Prodhan, 2001). The large vascular bundle contains 4-5 strands of xylem (Fig. 2). The number of xylem strands in the small vascular bundle is one or two. The xylem strand consists of proto- and meta-xylem vessels. Protoxylem vessel remains towards the centre while metaxylem vessel towards the periphery. The vessels are arranged radially. The vessels are round or oval with prominent secondary thickening (Fig. 2). The widest vascular cylinder was observed in S. rostrata $(190.99 \mu \mathrm{m})$ and it was statistically identical in S. bisponosa $(187.48 \mu \mathrm{m})$ however, the lowest value $(154.19 \mu \mathrm{m})$ was observed in S. sesban. Phloem thickness was maximum in S. bispinosa $(32.41 \mu \mathrm{m})$ while the other three species exhibited identical results. The thickness of the sieve tube wall was highest in both $S$. cannabina and $S$. rostrata and it was statistically insignificant to $S$. bispinosa, however, it was statistically identical with $S$. sesban (Table 1). The primary phloem consists of several sieve elements and a lot of parenchymatous cells. The first phloem appears in the external parts and xylem in the internal part of a pro-cambial filament. New phloem elements appear closer to the middle of the stem and the xylem differentiates oppositely. The vascular cambium arising in the two positions are called fascicular and inter-fascicular cambium (Prodhan 
and Sarkar, 2002; Sarkar and Prodhan, 2001). Prodhan and Sarkar (2002) stated that a large vascular bundle consists of a lot number of sieve tubes and parenchymatous cells while in the small bundle are parenchymatous tissue with or without functional sieve element. Just beneath the endodermis, there was a discontinuous bundle cap (Fig. 2). The thickness of the bundle cap was statistically significant and the highest bundle cap thickness was found in S. cannabina which was statistically identical to $S$. rostrata and $S$. bispinosa whereas the lowest thickness was found in $S$. sesban (Table 1). At maturity, the cambial zone is composed of 1-3 layers of cells (Fig. 2). Cambial thickness was the maximum in S. sesban and it was statistically similar to $S$. rostrata, however, S. cannabina exhibited minimum cambial thickness. Prodhan and Sarkar (2002) reported that at an early stage, the cambium becomes active and gives rise to secondary phloem and secondary xylem. In the active stage, the cambial zone consists of 4-5 layers of cells consisting of cambial initiates and their derivatives.

Xylem thickness was the highest in $S$. rostrata $(121.65 \mu \mathrm{m})$ which was statistically identical to $S$. bispinosa $(118.28 \mu \mathrm{m})$ and the lowest $(85.17 \mu \mathrm{m})$ in S. sesban (Table 1). The thickness of the metaxylem vessel showed statistically significant results among the four species. The highest value was found in S. bispinosa $(93.0 \mu \mathrm{m})$ followed by $S$. rostrata $(74.4 \mu \mathrm{m})$, S. sesban $(62.2 \mu \mathrm{m})$ and $S$. cannabina $(39.7 \mu \mathrm{m})$. The protoxylem vessel thickness was highest in $S$. bispinosa which was statistically similar to S. sesban and lowest in S. cannabina. Prodhan and Sarkar (2002) reported that the increase of secondary xylem was a result of secondary growth. They further stated that the secondary phloem lies abaxial to the cambial zone. The secondary phloem consists of sieve elements, phloem parenchyma and phloem fibre. Among the elements of secondary phloem, axial parenchyma has been found to occupy the major area. The phylogenetic (cladistics) relationship of different Sesbania species manifested that $S$. bispinosa and S. rostrata are closer species (Farruggia et al., 2018) which are in an agreement considering most of the anatomical vascular features of these taxa (Table 1). Chanda et al. (2021) explained the morphological and physiological characteristics of different Sesbania species and gave information about the close similarities of $S$. rostrata and $S$. bispinosa according to their stem base diameter. These findings also supported the close anatomical relationship between the $S$. bispinosa and $S$. rostrata. From the same study, the highest biomass yield was obtained from S. bispinosa (Chanda et al., 2020a) which also justifies the highest vascular cylinder, bundle cap, phloem, xylem, proto- and metaxylem vessel thicknesses of $S$. bispinosa. The larger vascular components helped to transfer water and minerals from soil to leaves, and photosynthates from source to sink, which might be the inherent cause of higher biomass yield in S. bispinosa.

Pith

Pith occupies the central portion of the stem. The area of pith peripheral cell was statistically significant in S. cannabina, S. bispinosa and S. rostrata, however, insignificant in $S$. sesban (Table 1). The highest significant area of the pith central cell was found in S. bispinosa $\left(387.6 \mu \mathrm{m}^{2}\right)$ and other Sesbania species showed identical results. Prodhan and Sarkar (2002) reported that the pith is the central core of the stem and is composed of thin-walled parenchymatous cells.

A dichotomous key of four Sesbania species based on stem anatomical descriptors -

1a. Epidermal parenchyma cell $850-1010 \mu \mathrm{m}^{2}$, cuticle thickness $6.0-6.5 \mu \mathrm{m}$, hypodermal collenchyma width 110-145 $\mu \mathrm{m}$, endodermal parenchyma width $20-25 \mu \mathrm{m}$, protoxylem vessel diameter 40-45 $\mu \mathrm{m}-2$

1b. Epidermal parenchyma cell $650-700 \mu \mathrm{m}^{2}$, cuticle thickness 7.0-7.7 $\mu \mathrm{m}$, hypodermal collenchyma width $160-180 \mu \mathrm{m}$, endodermal parenchyma width $26-35 \mu \mathrm{m}$, protoxylem vessel diameter $25-30 \mu \mathrm{m}-3$ 
2a. Epidermal parenchyma cell width 27-29 $\mu$ m, epidermal parenchyma cell wall thickness 4.5-5.0 $\mu \mathrm{m}$, hypodermal collenchyma cell $960-970 \mu \mathrm{m}^{2}$, vascular cylinder width $150-160 \mu \mathrm{m}$, sieve tube cell 410-420 $\mu \mathrm{m}^{2}$, xylem thickness $80-90 \mu \mathrm{m}-$ S. sesban

2b. Epidermal parenchyma cell width 23-24 $\mu \mathrm{m}$, epidermal parenchyma cell wall thickness 3.3-3.7 $\mu \mathrm{m}$, hypodermal collenchyma cell 735-745 $\mu \mathrm{m}^{2}$, vascular cylinder width $180-190 \mu \mathrm{m}$, sieve tube cell 865-875 $\mu \mathrm{m}^{2}$, xylem thickness $110-125 \mu \mathrm{m}-$ S. bispinosa

3a. Epidermal parenchyma cell wall thickness $1.45-1.60 \mu \mathrm{m}$, hypodermal collenchyma cell 810-820 $\mu \mathrm{m}^{2}$, cortical parenchyma cell width 60-65 $\mu \mathrm{m}$, endodermal parenchyma cell 1200-1250 $\mu \mathrm{m}^{2}$, vascular cylinder width $170-180 \mu \mathrm{m}$, sieve tube cell $630-660 \mu^{2}$, xylem thickness $90-100$ $\mu \mathrm{m}-$ S. cannabina

3b. Epidermal parenchyma cell wall thickness $4.2-4.4 \mu \mathrm{m}$, hypodermal collenchyma cell 620 $630 \mu \mathrm{m}^{2}$, cortical parenchyma cell width 30-35 $\mu \mathrm{m}$, endodermal parenchyma cell 1000-1050 $\mu^{2}$, vascular cylinder width $185-197 \mu \mathrm{m}$, sieve tube cell 710-730 $\mu \mathrm{m}^{2}$, xylem thickness $118-125 \mu \mathrm{m}-$ S. rostrata

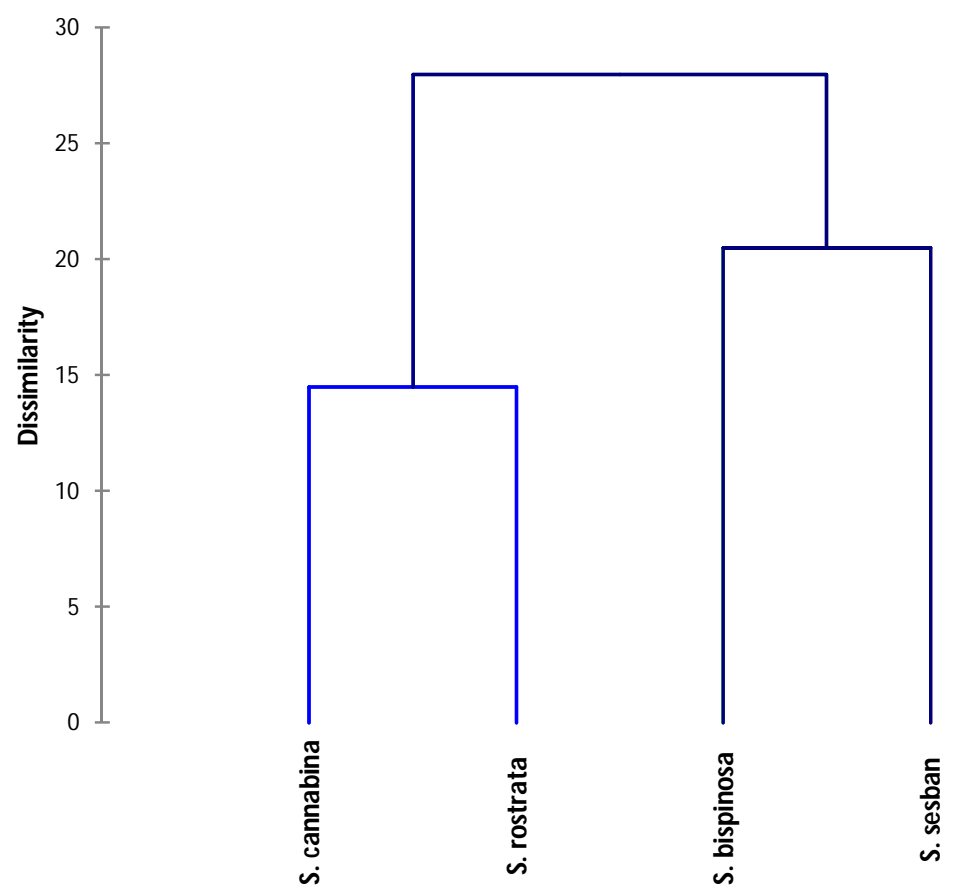

Fig.3. Agglomerative Hierarchical Cluster analysis dendrogram based on quantitative stem anatomical descriptors.

\section{Multivariate analysis of quantitative stem anatomical descriptors}

Agglomerative clustering is the most common type of hierarchical clustering used to group objects in clusters based on their similarity, resulting in a tree-based representation of the objects, named dendrogram. The dendrogram, based on stem anatomical descriptors, identified two distinct clades indicating the close relationships between $S$. bispinosa and S. sesban vs. S. cannabina and $S$. rostrata (Fig. 3). The close relationships were also well represented in both morphological (Chanda et al., 2020b) and molecular data (Farruggia et al., 2018). Farruggia et al. (2018) also 
concluded that $S$. rostrata might be a probable ancestor of S. bispinosa and S. sesban, although the closest similarity in morphological descriptors between S. bispinosa and S. cannabina in the field. Sesbania sesban possessed a relatively lower amount of lignified xylem, phloem fibres and xylem fibres which made it more digestible as animal forage (Guines et al., 2003).

From the results, it is evident that S. bispinosa and $S$. rostrata exhibited more or less similar results in terms of stem anatomical descriptors - epidermal, cortical and vascular bundle, which is also an indication of the close phylogenetic relationship of these two taxa. In addition, S. rostrata and $S$. cannabina were closer to some extent according to some anatomical descriptors that also justifies the external morphological similarities of these species. It might be concluded that quantitative stem anatomical descriptors could be useful to identify Sesbania species especially phenologically and floral morphologically similar, S. bispinosa and S. cannabina. Anatomical variations observed in Sesbania species need further studies, mainly from eco-physiological points of view, for a better understanding of plant adaptations to diverse ecosystems.

\section{Acknowledgements}

We acknowledge the financial support of the Ministry of Science and Technology, Government of the People's Republic of Bangladesh. We thank anonymous reviewer(s) for careful readings, helpful suggestions and engaging discussion, which improved the text considerably.

\section{References}

Ahmed, Z.U., Hassan, M.A., Begum, Z.N.T., Khondker, M., Kabir, S.M.H., Ahmad, M. and Ahmed, A.T.A. 2009. Encyclopedia of Flora and Fauna of Bangladesh, Vol. 8. Angiosperms: Dicotyledons (FabaceaeLythraceae). Asiatic Soc. Bangladesh, Dhaka. pp. 171-175.

Allen, O.N. and Allen, E.K. 1981. The Leguminosae: A Source Book of Characteristics, Uses, and Nodulation. University of Wisconsin Press: Madison, WI, USA. pp. 1-806.

Aziagba, B.K. and Okeke, C.U. 2017. Taxonomic significance of stem and petiole anatomy of three white varieties of Vigna unguiculata (L.) Walp. Arch. Agric. Environ. Sci. 2: 109-112.

Barykina, R.P. and Kramina, T.E. 2006. A comparative morphological and anatomical study of the model legume Lotus japonicus and related species. Wulfenia 13: 33-56.

Branzini, A., González, R.S. and Zubillaga, M. 2012. Absorption and translocation of copper, zinc and chromium by Sesbania virgata. J. Environ. Manag. 102: 50-54.

Chanda, S.C., Abdullah, M.R., Razzak, M.A. and Sarwar, A.K.M. Golam. 2021. Morphological and physiological characterization of Sesbania genotypes. Legume Res. 44: 1087-1091.

Chanda, S.C., Hossain, M.A., Rahman, M.M., Shamsuzzaman, A.N.M. and Sarwar, A.K.M., Golam. 2019 a. Regional variation in agro-morphological descriptors of Sesbania bispinosa (Jacq.) W. Wight. Bangladesh J. Bot. 48: 289-295.

Chanda, S.C., Prodhan, A.K.M.A. and Sarwar, A.K.M., Golam. 2018. Morphological descriptors of seed and seedling for identification of dhaincha (Sesbania spp.) accessions. Bangladesh J. Bot. 47: 237-246.

Chanda, S.C., Razzak, M.A., Hossain, M.A. and Sarwar, A.K.M. Golam. 2020a. Biomass yield enhancement of dhaincha (Sesbania species) through cultural practices. Agron. Res. Moldavia 53(2): 160-176.

Chanda, S.C., Razzak, M.A., Haque, M.E. and Sarwar, A.K.M. Golam. 2020b. Multivariate analysis of morphological descriptors for identification of Sesbania Scop. accessions. Bangladesh J. Sci. Indus. Res. 55: $215-220$.

Chanda, S.C., Sagar, A., Islam, M.M., Hossain, M.A. and Sarwar, A.K.M., Golam. 2019b. Phenology and reproductive biology of three Sesbania species. Int. J. Minor Fruits Med. Arom. Plants 5: 29-37.

De Faria, S.M., Lewis, G.P., Sprent, J.I. and Sutherland, J.M. 1989. Occurrence of nodulation in the Leguminosae. New Phytol. 111: 607-619. 
Evans, D.O. 1990. What is Sesbania? Botany, taxonomy, plant geography and natural history of the perennial members of the genus. In: Macklin, B. and Evans, D.O. (Eds). Perennial Sesbania species in Agroforestry Systems. Nitrogen Fixing Tree Association, Hawaii. pp. 5-19.

Farruggia, F.T., Lavin, M. and Wojciechowski, M.F. 2018. Phylogenetic systematics and biogeography of the pantropical genus Sesbania (Leguminosae). Syst. Bot. 43: 414-429.

Gillett, J.B. 1963. Sesbania in Africa (excluding Madagascar) and southern Arabia. Kew Bull. 17: 91-159.

Gomez, K.A. and Gomez, A.A. 1984. Statistical Procedures for Agricultural Research. 2nd Ed., John Wiley and Sons, New York. pp. 1-680.

Guines, F., Julier, B., Ecalle, C. and Huyghe, C. 2003. Among and within-cultivar variability for histological traits of lucerne (Medicago sativa L.) stem. Euphytica 130: 293-301.

Laladhas, K.P., Cheriyan, V.T., Puliappadamba, V.T., Bava, S.V., Unnithan, R.G., Vijayammal, P.L. and Anto, R.J. 2010. A novel protein fraction from Sesbania grandiflora shows potential anticancer and chemopreventive efficacy, in vitro and in vivo. J. Cell. Mol. Med. 14: 636-646.

Metcalfe, C.R. and Chalk, L. 1950. Anatomy of the Dicotyledons (Leaves, stem and wood in relation to taxonomy with notes on economic uses). Oxford University Press, Clarendon Press, London.

Mythilli, T. and Ravindhran, R. 2012. Phytochemical screening and antimicrobial activity of Sesbania sesban (L.) Merr. Asian J. Pharm. Clin. Res. 5: 179-182.

Nohwar, N., Khandare, R.V. and Desai, N.S. 2019. Isolation and characterization of salinity tolerant nitrogen fixing bacteria from Sesbania sesban (L.) Merr. root nodules. Biocat. Agric. Biotechnol. 21: 101325.

Nwachukwu, C.U., Edeoga, H.O. and Kemka-Evans, C.I. 2017. Stem anatomical studies of some species of Indigofera L. (Leguminosae-Papilionoideae). Int. Res. J. Plant Crop Sci. 3: 24-29.

Pandey, B.P. 2007. A Text Book of Botany Angiosperms. S. Chand and Company Ltd., New Delhi. pp. 1990.

Powell, R.G., Smith, Jr. C.R. and Madvigal, R.V. 1976. Antitumor activity of Sesbania versicaria, S. punicea and S. drummondii seed extracts. Planta Medica 30: 1-8.

Prodhan, A.K.M.A. and Sarkar, D.N. 2002. Root and stem anatomy of Sesbania rostrata. Indian J. Agric. Res. 36: 1-9.

Prodhan, A.K.M.A., Hossain, M.Z., Sarwar, A.K.M. Golam. 1998. Stem anatomy of Sesbania formosa. Abs. Sec. (ii), $20^{\text {th }}$ Bangladesh Sci. Conf., Bangladesh Univ. Eng. Technol., Dhaka, November 28-30, pp. 3-4.

Qadir, M., Qureshi, R.H. and Ahmad, N. 2002. Amelioration of calcareous saline sodic soils through phytoremediation and chemical strategies. Soil Use Manag. 18: 381-385.

Ruzin, S.E. 1999. Plant Microtechnique and Microscopy. Oxford Univ. Press, USA. pp. 1-336.

Sahi, S.V., Bryant, N.L., Sharma, N.C. and Singh, S.R. 2002. Characterization of a lead hyperaccumulator shrub, Sesbania drummondii. Environ. Sci. Technol. 36: 4676-4680.

Sarkar, D.N. and Prodhan, A.K.M.A. 2001. Anatomy of Sesbania sesban. Indian J. Agric. Res. 35: 211-218.

Sarwar, A.K.M. Golam, Islam, A. and Jahan, S. 2015. Characterization of dhaincha accessions based on morphological descriptors and biomass production. J. Bangladesh Agril. Univ. 13: 49-54.

Yang, B., Shu, W.S., Ye, Z.H., Lan, C.Y. and Wong, M.H. 2003. Growth and metal accumulation in Vetiver and two Sesbania species on lead/zinc mine tailings. Chemosphere 52: 1593-1600.

(Manuscript received on 8 July 2020; revised on 1 December 2021) 